\title{
Wildflowers, Nationalism and the Swedish Law of Commons
}

\author{
GUDRUN DAHL
}

Department of Social Anthropology

Stockholm University

\begin{abstract}
In post-war Sweden, overt demonstrations of political nationalism have been considered bad taste. In middle-class culture, the construction and emotional charging of Swedishness have instead taken place in terms of an idiom of love for nature. Conceptions of freedom and equality are by this idiom tied up with symbolic references to childhood and to the flora of forests and meadows. The Swedish 'Every Man's Law' regulating access to flowers and berries and mobility in the natural landscape in this context comes to stand as a central national symbol.
\end{abstract}

\section{1. 'NATURE-LOVING' AS NATIONALISM}

In his book on Banal Nationalism Billig (1995) argues that in order to understand nationalism, social scientists have concentrated too much on its extreme expressions. They have disregarded in their analyses the everyday processes that maintain ideas and feelings of national identity during periods when the survival of the nation is not directly at stake, when the fervour of nationalist feeling has turned into routine (op.cit.: 41). In the present paper I want to take Billig's notion of 'Banal Nationalism' as my point of departure and reflect on my own cultural environment - as somebody who grow up in the modernist 'folkhem' culture of Sweden in the fifties and sixties. In particular, I want to deal with the issue of Swedish Nature as a neutral focus of nationalism in a setting where explicit nationalism was not just 'routinised' but even socially disapproved and where the use of conventional symbolism was constrained. I will do so by discussing how the the two themes of nature and freedom are interlinked in two contexts: one, the celebration of summer in public ritual and in popular ballades, and the other, discourse on the 'Allemansrätt', the Swedish Law of Commons.

This attempt is also (to myself) an experiment in finding the boundaries of possible reflexivity. Noting in myself an emotionally strong rejection of nation- 


\section{GUDRUN DAHL}

alism, yet at the same time a deep attachment to Swedish nature and the Swedish summer, I want to find out in an introspective way, where in myself lies the link between Swedishness and a particular way of relating to Nature? Where did it get its emotional grounding? Is it at all possible to achieve distanced reflexivity in relation to central aspects of your own identity? Writing about views which are central to your own culture in a constructionist mood is not without pain. We do not like to think of our own values as less than evident. To an audience of your own background whatever you say may be seen as stating the trivial, while when you adress an international audience, you may not be able to perceive the limits of that which is taken-for-granted and commonly shared, thinking that you and your audience all represent a generalised modern West. In terms of the construction of nationalism even the differences between Scandinavian cultures are big enough to make them worthwhile objects of scrutiny.

I started to write this paper with the ambition to write in a neutral way about the Allemansrätt as a cultural symbol. It stands for a cluster of images that tie together Swedishness, childhood, freedom and the particular Swedish landscape. On the way I stumbled on a book fresh from the print written by a Swede in order to 'dismantle the myth' of the Allemansrätt. I found that the book upsets me: but on the other hand, it also reminds me of the limitations of my own perspective even within Sweden. The ethnography presented here, then, represents not only the views of a certain Swedish generation, but also reflects urban middle class values.

In a TV panel on biologism December 14th, 1996, which I turned on as a pastime from writing this paper, the programme presenter suddenly exclaimed 'But I guess it is hardly controversial to say that Swedes are nature-lovers'. Avoiding the issue whether this as a statistical statement is true, it is certainly received wisdom for Swedes as to what makes us distinct from others. Frykman and Löfgren (1987) have traced Swedish bourgeois love for nature to the turn of the century when writers, artists and scholars searched in the landscape and in history for an identity different from the one suggested by the conservative and martial patriotism of earlier generations (pp. 57-9). Progressive liberals 'embraced a cult of the simple, the genuine and the natural...' (n.5 p.58). Nature was animated into a symbol for Swedishness and a national fellowship above class boundaries. Now it was no longer the wild mountains or the stormy coast that were the favourite landscape but rather the nostalgic and melancholic settings; the whispering pine forest, the silent starry winter night, the grove of young birch trees, the wood anemones in the forest clearing. The dramatic and exotic landscapes gave way to the intimate and melancholy, but still it was the solitary landscape, uncontaminated by human presence, that was preferred. Sverker Sörlin (1988) argues that particularly the forest became an important national symbol through its potential to point both back to a virgin natural state and forwards to the industrial future. 
Seen from the outside, something that distinguishes Sweden is its depressingly long winter. Nevertheless, the internal discourse of what is worth loving in Sweden, or about the proper relation to Nature can not be understood apart from Swedish summer as a key symbol. Frykman and Löfgren ( p. 64-7) note that already at the turn of the century it was an established bourgeois pattern to 'equate nature with the summer and to anchor the nostalgia for nature in the delights of summer vacations'. I am not able to say to what extent immigrant Swedes today share these values, but public $S$ wedish culture still presents escape from the town into a summer cottage of your own, going 'på landet' as an important value, something a good parent should make possible for her children.

Hylland-Erikssen (1995) notes a difference between Swedish and Norwegian national symbolism, arguing that the former is linked to modernity whereas the latter is turning back, romanticising history and the peasantry. This may be a matter of degree and needs some qualification. Swedish bourgeois National Romanticism at the turn of the century did in fact also look back into a romanticised peasant life. There are forms in which this romanticism lives on in for example contemporary preferences for old cottages, in ideas about authentic forms of celebrating midsummer, in the preference of archaic flower names in order to evoke a sense of genuine Swedish summer. Much of what urban Swedes associate with typical Swedish 'nature', and the items usually singled out to evoke notions of summer, pertain to biotopes created by farming and human use over a millennium. Large parts of the Swedish forests are characterised by relatively young vegetation, secondary forest that has been harvested and managed over time, rather than virgin forest. Up to the expansion of the timber and iron industry, which demanded large cropping of forest for charcoal production, parts of it were grazed or harvested for leaves to be used as fodder, usually on the basis of village commons. The most common flowers associated with midsummer, such as bluebells, red clover, marguerites, or buttercups are also flowers of grazed meadows.

While the plants which stand as symbols of nature, and of Swedishness, thus often belong to an anthropogenic landscape created by farmers, farming itself is less emphasised in today's rural romanticism. Perhaps this is because there is little similarity between a modern farmer and the fantasised historical peasant. However, just as the English expression 'country' relates both to the territory of a nation and to the rural 'countryside', Swedish 'Iandet' has double sets of connotation. 'Ilandet' means ' in the country' while 'på landet' means 'in a rural setting' . Further, there are no strong boundaries maintained between going ' $u t$ $p a ̊ a l$ landet' and 'ut $i$ naturen', although 'på landet' gives more space for associations to rural life, rural economy. Rurality and naturality therefore are conflated.

To the urban summer visitor, social access to a rural community is not unproblematic unless the person has personal kin relations. The forms for 


\section{GUDRUN DAHL}

interaction available have changed: I remember both ' jumping in the hay' and travelling on the hay cart, drawn by a horse, at the hay harvest, or going to buy milk freshly drawn from the cow from a farmer. These were classical highlights of a middle-class summer vacation in the fifties, but I have not been able to offer the same entertainment to my own children, whose images of farming life have been shaped by media representations, e.g. children's fiction, where rural life is probably over-represented. Note that Sweden is sparsely populated and rural activities as such are not very visible: you see farmsteads, meadows, cattle as you travel in the countryside, but usually not many people moving about. Hence going ' $u t$ pa landet' may entail indulging in a meeting with a non-urban landscape rather than confronting rural people in their daily life. The discourse and symbolism surrounding summer and nature - or what makes up a Swedish Christmas - on the other hand contain many fictional references to peasant life as a way of authenticating experience, even if the peasants themselves are no longer held forth as important symbols.

\section{PUBLIC CELEBRATIONS OF SUMMER - MIDSUMMER}

One example of this is the celebration of Midsummer. Generally one can say that to many urban Swedes the seasonal aspect of festivals is more important than the Christian aspect. Midsummer, originally The Feast of Saint John, presumably once contained elements of reverence for the saint but that has now been lost. Today, the whole event is commonly assumed to be a very traditional Swedish continuation of some pagan fertility cult. True or not, Midsummer is a contemporary practice about which there is widespread agreement as to what it means and how it should be undertaken, even if the realisation in most cases fall short of the script. In practice, the celebration of Midsummer falls into two parts. The first is concerned with the raising of the maypole. The pole itself can have different shapes but is usually clad with birch leaves and decorated with wreaths of birch leaves embellished with meadow flowers. There is usually 'folk music' and 'folk dancing' in standardised provincial folk dresses, and ring dance games for the children. The event is presented as for the benefit of the children. Adults take part in the games to make it possible for the children to take part, which the latter are not always eager to do, if they are shy. Nevertheless it is believed to be a nice thing, a nice tradition to remember. Adults are not very likely to seek these games out for their own entertainment other than as audience: this is rather symptomatic for Sweden, where celebrations are often seen as more important for children than for adults, and where often the children themselves are supposed to stage the performances involved. The second part, or alternative form, of the celebration is a barn or bridge dance for adults, with 'traditional' as well as modern dancing in a barn or on a landing stage decorated with fresh branches of birch. At Midsummer the sun sets for only one hour, if at all. The 
night is supposed to be romantic and midsummer is also a popular time to have a wedding. If you are young, to just sit at home at Midsummer's Eve is potentially very depressing. Very young girls follow the custom of picking seven different types of flowers to put under the pillow in order to dream about the future husband. Flowers, Swedish tradition, and dancing are the explicit themes that govern the event, a usually more implicit context being the mystic folkloristic forces active in the short night.

Midsummer is well-known as a symbol of Swedishness. It is also the focus of a large sector of emblematic representations of Swedishness, used in decorative prints, postcards, advertising etc. In these images flowers are an important part - usually a combination of the most common meadow flowers, such as red clover, marguerites, bluebells, buttercups and wild chervil. The fact that these flowers are common to all of Northern Europe does not mean that e.g. text-less postcards with such a motive will not be immediately read by the native Swede as referring to Swedish summer, and not to any other summer. Just as the flag, as Firth (1973) observed, is a condensing symbol, the bunch of flowers is like an officially wholly unrecognised but yet efficient way of 'flagging the nation'.

\section{THE IMPROPRIETY OF WAVING THE BANNERS}

Open nationalism is not officially condoned in Sweden, outside sports contexts. I remember following my parents and grandfather to what was most probably my life's last celebration of 'Svenska Flaggans Dag' somewhere back in 1951. Then it was still seen as a proper way of spending a bourgeois Sunday. The fifties however saw the breakthrough of modernism in Sweden and were a time of rapid changes. By ten years later such celebrations drew a very small attendance. The youth organisation of which I was a member in the early sixties had left-over issues of song-books edited and printed in 1951. Their main use were as blocks for autographs from friends that you met at the national conferences and meetings. Most of the songs seemed completely out of date already in 1962: they contained phrases such as ' Here are young wills, full of go, dash and swift action. Our banner carries the sign of the sun, and that fresh wind folds it, which gives light and day'. Youths, sun, strength of will, the day. These were symbols and values which had been lavishly used in the thirties and forties in political contexts far outside the extreme right, but which at the time of my early youth had become tainted by the latter connection: not that they were immediately seen as Nazi symbols, but an absolute feeling of out-modedness was attached to them.

Much of the cultural heritage of Norway and Sweden is shared. Our experiences during the war were different, however: while patriotism to the Norwegians acquired a positive meaning as a way of standing up against a foreign oppressor, the war left a feeling in Sweden that the symbols of potential patriotism produced in the era of National Romanticism had been appropriated 


\section{GUDRUN DAHL}

by the same oppressor. They were something one should try to distance oneself from rather than use. For example an overuse of old Nordic imagery was shunned.

The international literature sometimes makes a differentiation between 'patriotism' and 'nationalism': Americans allegedly feel that patriotism is the innocent and virtuous love for one' s own country whereas nationalism is fanatic and aggressive, a distinction which has crept also into some sociological texts (See Billig p. 56). However, neither word has any particularly positive value in mainstream Swedish culture. This of course does not mean that Swedes are not fond of their country. In the seventies 'patriots' could be heard as a positive term about others, the heroes in distant liberation movements, but it would still have appeared rather odd for a Swedish youngster to claim himself or herself to want to be a patriot. However, there is a change in this, and runes and ancient stone carvings are used to a new extent, both in allegedly 'secular' form and integrated into neo-racist symbolism. One can say that to the extent that Swedish nationalism existed in the era between the war and the outbreak of anti-immigrant feelings and skinheadism in the early 1990's it was expressly dressed as nonnationalist. There were also informal limitations on the use of flags: they were posted outside government buildings and sometimes at shops or homes, but in the latter case usually only to signal festivity. Rather than being the focus of celebration, they were a means of marking ritual time. Just like lit candles in the winter mark that you enter a different kind of temporal existence, the single flag on the flagpole simply signalled that somebody was dead or had a birthday.

\section{PUBLIC CELEBRATIONS OF SUMMER - THE BREAKING UP}

One of the themes elaborated by Bourdieu (e.g. 1977/1970) is how the State through the school has the power to produce and impose the categories of thought which we use to understand among other things the State itself. The Swedish school as I have seen it both as a child in the fifties and sixties and as a parent in the eighties and nineties has at least on the surface been more concerned with conveying environmentalism and internationalism than with fostering nationalism. There is no daily saluting of flags as e.g. in USA (Billig, op.cit. p. 50) or even at the breaking-up day before summer vacation, the most important ritual event in Swedish schools. Although there might have been the occasional flag, especially the main one at the school's flagpole, overt nationalist symbolism played no important role in the ceremony as I experienced it as a child. There was also no saluting of the constitution, nor any honouring the King or the Government as is done in some other countries. If the national anthem was sung, it was certainly not seen as central to the occasion. In secondary school, we were made to celebrate the death day of Gustavus II Adolphus, 6th of November, to honour him as the founder of the city of Gothenburg. This was an expression of local 
rather than national chauvinism. Nevertheless, about 1964 this custom was dropped due to pressure from pupils who saw the object of celebration too much as a nationalist war hero to be cherished by modern Swedes. The Day of the Flag, the 6th of June, was never celebrated in my school, except perhaps by the janitor hoisting the flag itself. Sweden had no official National Day until the latest bourgeois government promoted the Day of the Flag to this status. Thus, there is no tradition even faintly similar to the 4th of July for the Americans or 17th of May for our Norwegian neighbours. This did not mean that the children of the folkhem were not bombarded with messages of what it meant to be Swedish. Rather, Swedishness tended to be and still is continuously celebrated in schools, but in a way which largely rejected the use of the internationally established repertoire of nationalism and patriotism.

The term ending was, as it remains today, an emotionally charged event. Sweden has only two school semesters: the school year starts in late August and with a break for Christmas goes on until about the 10th of June. There is then about 9 to 10 weeks of summer holiday: not only does the break up take place at the loveliest part of the year, it is also a release for a substantial period of freedom. The ceremony usually consists of a formal speech in the main hall or school yard by the headmaster and summer songs sung by the children. What the speech is supposed to contain is not to my knowledge regulated, but a breach of the code can reveal expectations, as some years ago in my son's school. The headmistress told a little story about a girl wishing for a bird. 'Her mother brought a closed box and put it on the table, admonishing the girl not to lift the lid until mother was back. The girl could hear a noise from the box and became curious...' - and at this stage of the tale, the attending parents were speculating about the moral conclusion to come. Would it be an encouragement of care for birds? Would it be something about being let out from confinement? Would it be an encouragement of curiosity? - all these were seen as appropriate moralities. However, the headmistress told us that 'The girl let the bird out. Of course her mother was enraged. She told the girl: you should have been obedient. Now you cannot have the bird.' A loud sigh of astonishment was heard. As we left the hall, parents expressed their rage and back in the classroom the primary school teacher felt compelled to counter the story told by her boss with another one: a story of how she herself had saved a bird trapped in a ventilation funnel. She told the children how she had come to love that particular bird although she disliked the species. We all shared the idea that children should not at the start of their leave be told to be obedient and forget their natural curiosity: on the contrary, they should be encouraged to run around and learn from the environment while they were away from school and to care for birds and other animals. Care for Nature is in this anecdote conceptually linked to notions of freedom and childhood.

These connotations also colour the emotionality of the event. In spring 1997 , Expressen, one of the main Swedish tabloids, launched a campaign to merge the 


\section{GUDRUN DAHL}

school ending with the Day of the Flag, for the explicit purpose of enabling the celebration of the National Day to benefit from this very emotionality.

\section{BALLADS OF FLOWERS AND FREEDOM}

The repertoire of songs sung at the term end ceremony has changed somewhat since my childhood but the themes are the same. They represent a genre which is very popular in Sweden, and which has strong connotations of Swedishness, much in the same way as images of bunched flowers do - and they also contain verbal collections of floral names to convey the same message. One of the oldest songs of the genre still sung is the hymn 'The Flower Time approaches' (Den blomstertid nu kommer), ascribed by a somewhat insecure tradition to Israel Kolmodin (1643-1709), a theologist and Uppsala professor.

\section{The Flower Time Approaches}

The Flower Time comes with great joy and beauty:

Thou art approaching, sweet summer, when grasses and crops grow,

With benign and lively warmth to all that has been dead

The rays of sun come closer: all is born again.

The fair meadows, the noble grain crops of the fields,

The rich beds of herbs, the green trees of the grove:

They will remind us of the richness of God's blessing,

That we may reflect on the Grace that lasts all the year around

The literal meaning of the text is reminiscent of Linnaeus' (1707-1778) suggestion that one should enter Nature in order to see the back of God. This song is almost always sung at the final of the school year, and can without hesitation be said to mark the emotional zenith of that celebration. For Swedes of my generation, even a person coming from an atheist background like myself, the first four words of 'Den blomstertid nu kommer' are enough to evoke strong feelings. They stir strong memories of relief and exhilaration and images of happy children. The song has a religious message, but its main reference is in practice to summer as such, to continuity in Nature and through its poetic and somewhat archaic language, also to cultural continuity.

Evert Taube (1890-1976) was a prominent and productive poet and Swedish ballad singer. Although extremely popular he was never successful in getting enough literary recognition to gain a position in the Swedish Academy as many people thought he should. He wrote songs in a large number of genres, most of them suitable for sociable singsong. This is a common form of party entertainment in broad sectors of the Swedish society. For this reason, his songs are known by heart by most native Swedes. Among them are many songs on the joys 
of summer, following - or even setting a pattern for - the standard recipe of including long lists of floral names. For example, 'Rönnerdahl' is a song about the joy of life of the author's ageing alter ego. The old man steps up in the early morning to take notice of 'all the flowers unfolding in the meadow: cowslip, saxifrage, cat's foot and blue violets'. Already over 80 years old and with the status of living national saint, Taube wrote the film music for 'The Apple War'. This movie was produced by a well-known pair of radical comedians, Hans Alfredsson and Tage Danielsson.

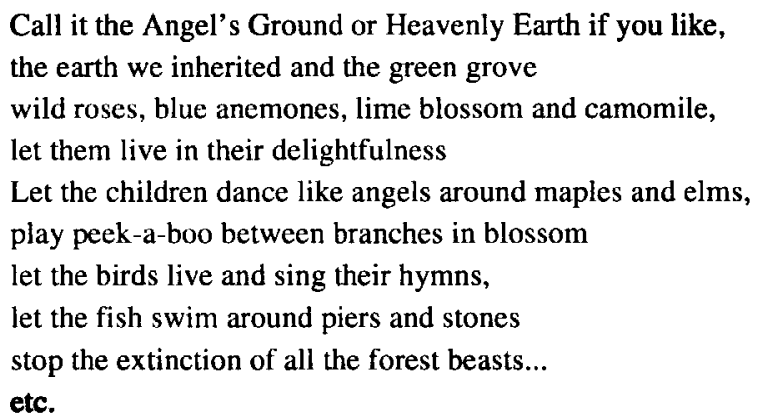

The film itself deals with the local response of an apple farming community in southernmost Sweden to the threat of foreign (read German) capitalist and landgrabbing interests. The main characters win the battle against the intruders partly by mobilising the local community of natural spirits, such as elves, against the machinery.

Taube's song quickly entered booklets with texts for community singing as well as the song programme of school celebrations. Other songs which have caught very quick popularity after they were written, and entered pamphlets with songs suitable for sociable co-singing, are 'Open landscapes' (Öppna landskap) by Lundell and 'Ida's summer song' by Lindgren.

Ulf Lundell is a rock-singer, text writer and novelist, previously listened to mainly by his own generation of 68 -ers, about whom he has also written a successful generation novel, 'Jack'. He seems to have written the song 'Open landscapes' rather consciously. Its first few bars coincide with a well-known song of spring, often heard on celebrations at the last of April. The content is more decidedly 'adult' than in summer songs generally. The author praises the open landscape, wishing to live close to the sea. The text emphasises in a positive way the opportunity offered by the countryside to be left alone ' in peace and freedom', far away from people who 'lock up or steal', but also a wish to hear at a distance the noises from celebrating people. In his resort at the seaside, the author claims to burn his own brandy, spicing it himself with Johannisört (S:t John's wort). The word 'Johannisört' has many connotations of Midsummer, nature, and archaism. It quickly locates the song in the Swedish summer song genre. This is enforced in the last verse when the author ties a garland of leaves 


\section{GUDRUN DAHL}

(something you normally do at Swedish midsummer) and puts it beside a stone at hand 'where runes were carved for us sometime long ago'. The latter is an innovation however, because midsummer garlands are not usually put down as commemorative wreaths at graves.

Despite its encouragement to indulge in illegal liquor production (symbolising liberty in relation to social constraints?) the song immediately broadened Lundell's audience. The dairy industry and the farmers' movement picked up the expression 'öppna landskap' to use in the marketing of milk and of the importance of a healthy agricultural economy. The song was even suggested in the press to be a more suitable national anthem than the one we have, 'Thou Old and Free'. Many Swedes feel attached to the present anthem (which by the way, also refers to the summer sky and green meadows), yet its text is seen as representing outmoded values, especially in the passage 'Thou are enthroned on memories from great ancient days, when, honoured, your name flew over the world'. The anthem is sung at very formal occasions, and in the context of international sports events to match other anthems. My impression is that its use has become more widespread amongst youngsters lately, like other expressions of nationalism. In 1992, after the emergence of Swedish skinhead neo-nazism, certain school head-teachers formally banned the anthem from use at school celebrations. As in the case of the flag, there has been the counter-argument that it is negative if extremists are given free range to appropriate our formal national symbols just by the fact that other people shy away from using them.

As hinted above there is in Sweden a linkage between the concepts of Nature, Summer and Childhood, relating to the idealised summer vacation. A connection may possibly be made between the cluster of childhood-summer-Swedishness and the older discourse of youth-light-nationhood, to which I referred above. Clearly they are variations on the same theme, with ideas of the young person as the pure, forward-looking being, the carrier of hopes for the future. Different periods have made quite different readings of these symbols. The concept of youth mobilised by the older symbolism is that of organised youths, a troop of marching youngsters with their hopeful eyes turned up towards lofty ideals, a scout ideal. The present image of childhood is very different, and especially, it is set in a context which connects it with freedom from disciplining. In this conceptual linkage between Nature and Children there may be an expression of the distinction illustrated by Ellen (1996) of a concept of Nature as 'space which is not human' (p.110) and 'nature as inner essence' (p.111). That is, children grow best as persons if they are not tightly constrained. Innocent and unspoiled they can benefit from being given freedom to follow their impulses in a space outside the constraints offered by society. This view comes through in 'Ida's summer song' by Astrid Lindgren.

Lindgren (b. 1907), famous authoress of children's literature, has produced a variety of literary elaboration on the complex of children-summer-freedom. She has certainly contributed to the importance of this cultural theme in the 
internal conception of what is typically Swedish. Ida, the little sister of Emil in Lönneberga, the naughty boy with a golden heart, sings:

Don't you believe there'd be summer

if someone not gave it a push

making it all somewhat sum-rish

so flowers come in a rush.

Having claimed to have caused the water to jump in the streamlet and the evening sky to turn pink and to have created other necessary attributes of summer, Ida claims in the last verse of the song to have made forest strawberries 'and other small and funny things that fit children when they are small'. Finally she argues that she is making 'funny places where the children can run around, and then the children will fill up with summer and their legs will fill up with running'. In the text by Taube quoted above, the same image of unhampered movement is conveyed by 'Let the children dance like angels around maples and elms, play peek-a-boo between branches in blossom', establishing also a poetic linkage between children and flowers which is very common.

Lindgren, the most widely read Swedish author abroad, builds on a tradition of writing fiction for children which dates back to the 1890s. This was the era of breakthrough for Swedish national romanticism, but also for literary products directly oriented for children as consumers (Zetterholm, 1969 p. 31). J. Nordlander in 1886 published a collection of children's literature, 'Svenska barnboken 111 '. Zetterholm, who has made an extensive analysis of the phenomenon, quotes the caption on the back page of the cover, noting the significance of its phrasing

...The content is from the beginning to end Swedish to the core (kärnsvenskt, an expression with connotations to the hard core of pine wood, kärnfuru) as without exception collected from the popular (folklig) heritage tale. Simple but juicy and aromatic flowers from mountain and valley, from lake and shore meet the readers here. They will surely mainly delight the fresh, open mind of the child.

Partners to the nationalist project at the turn of the century, primary schoolteachers (folkskollärare) spread the texts produced and often combined national romanticism with a zeal for popular education.

Among the various genres by which Zetterholm classifies the songs, he finds among others 'nationalist songs', 'romantic songs and songs of Nature' and 'seasonal songs'. The nationalist songs have generally all been lost from the contemporary repertoire. Writing in 1969, Zetterholm noted that they were often of small literary quality, and that the patriotic zest they conveyed had become difficult to digest (op.cit. p. 54). He noted about the songs on Nature that 'one of the most striking traits in the turn-of-the century children's song is the enormous amount of ballads on flowers. They are so numerous that there is reason to talk of a new cult of flowers.' There were models for such ballads in poetry written for adults by authors such as Albert Gellerstedt and Erik Axel Karlfeldt. 


\section{GUDRUN DAHL}

Although flowers were in the focus, there were also children's verses about mushrooms, different species of trees, especially the birch (björk) and the pine (fura) which were favourite symbols of the Swedish landscape.

The writer of children's lyrics Alice Tegner (1864-1943) and the picturebook artist Elsa Beskow (1874-1953) were among those who created literature particularly geared to an audience of children, constantly printed in new editions. Beskow's pictures combine a mastery of Art Noveau decorative ornaments with a realistic and detailed depiction of minute phenomena in Nature such as small animals, herbs, flowers, mushrooms or berries. Two of her most loved books, Putte in the Blueberry Forest and The Tomtebo Children are about characters of miniature size, looking recognisably as average Swedish children of the time when they were produced. These children move around in well-known and realistic micro-landscapes where snakes by their size appear as monsters and ordinary blueberry bushes look like tall trees. In other books, Beskow illustrated songs, not the least flower lyrics for children produced by Tegner or verses about anthropomorphised flowers.

Not only did these books and songs establish that an interest in the small details of flora and fauna was appropriate for children, they also introduced a metonymy between flowers and children. A contemporary example of this is a song by Barbro Lindgren, internationalist rather than nationalist in orientation.

\footnotetext{
'We are flowers, raise us with care.

We are the hope of the earth,

let us grow wild and bud.

We are flowers, do not break us.

Limitless is our glow.

Let us grow freely,

without violence and death.'
}

In its basic asking for creative non-interference, this modern children's song reminds of the basic ethos claimed for the Allemansrätt, to which we will now turn our attention.

\section{6. 'THE LAW OF EVERY MAN’.}

The Swedish 'Allemansrätt', translated as 'Every man's right' or 'The Public Right of Access' is a set of presently widely accepted principles governing access to Nature. It allows you to ramble at will on uncultivated land and in forests in the countryside, to move freely on lakes and in the sea, and provides rights to gather flowers and berries and branches that have fallen to the ground. (Moss, turf, stones, hazelnuts and wood-on-the-tree may not be taken). The right to camp for a night or so without the landowner's consent is usually included. 
During the last decade, the Allemansrätt has gained the position of an important national symbol as environmentalist values have grown in significance and Sweden's relation to other legal systems has been under reconsideration. For a long time, the principles were not established in Swedish formal law, but regarded as part of customary law. In 1991 the general rule was codified in the constitution as a protected exception to the exclusivity of property rights. The Allemansrätt is however still legitimised as customary, and the constitution mentions it but does not spell out in any detail.

During the last decade, the application of the right has also caused new problems, in particular in relation to tourism. To be hospitable with access is not that easy. In the summer of 1994, the tabloid Aftonbladet reported that landowner Per Norderfors from Mårdaklev at the boundary between Västergötland and Småland, had won his case in the Court of Appeal (Hovrätt) after 15 years struggle. He had seen the area around his homestead being continuously destroyed by rapids-shooters and canoeists and finally sued a Danish travel agent for arranging trips to his grounds without the landowner's consent. The travel agent denied being alone in arranging rapids-shooting around the Norrströmmen rivulet or that he was threatening the natural surroundings. There were other agents than him, he said, and his activity was just renting out equipment. Apart from that, he was careful in informing his clients. In his defence he referred to the Allemansrät and the possibilities offered by customary law. In the first legal instance, the district court (tingsrätt), the travel agent was deemed right, whereas the next instance supported the landowner. In the magazine interview the landowner pointed to the future transfer of land to the next generation and his own responsibility for continuity: 'You have to protect what you have inherited'. He argued that his concern was not that he himself was disturbed, but that Nature was. The director in charge of such issues at the National Department for Management of Natural Resources in turn said that 'The idea cannot be that somebody should be able to make a profit out of the Allemansrätt'. In 1996 the case reached the Supreme Court. They ruled that the use of somebody else's land is not allowed if it causes notable damage or disadvantage to the owner, which was considered to be the case at hand. The case was seen as a precedent enforcing one important limitation to the Allemansrätt, but in fact the limitation already has a centuries-old backing. The Court did not want to rule out commercial use of the Allemansrätt altogether. There are advantages with arranged journeys to inaccessible places, it was said. The door is thus still open for wilderness tourism, a business branch for which Sweden with its rising unemployment has great hopes.

A caption for one of the images in the quoted Aftonbladet article of 1994 summarises the way public discourse on the issue has been shaped:

'While the Allemansrätt has decidedly vague contours, it is among the most Swedish things we have, and a permanent source of bragging whenever Sweden is marketed abroad. Interjected between Norrlandic views, royal children and folk dancing it 


\section{GUDRUN DAHL}

represents the linkage between Nordic longing for freedom and democracy. The right of all of us to take delight in the Swedish Angels' Ground irrespective of race, religion and economic status. A custom with thousand year old roots, existing in the vacuum between ordinary laws and regulations. A right to freely exploit when all laws have been written. There is just one little catch. It has never been written down. While visiting tourists learn that fermented Baltic Herring stinks, that the king loves walking in the forest and that hambo is danced in three-four-time, there is really not one single document that tells what to expect from the Allemansrätt'.

Today however, there is plenty of such written information available, perhaps as a response to the intensification of the public debate on Allemansrätt in the context of the vote on Sweden's entrance to the EU. There are several pamphlets on the topic. The Scout movement, the National Environment Protection Board, other organisations and some local communities have put out information on Internet. A separate booklet has been produced to the benefit of immigrants. In this information literature, certain themes recur: The first is that the Allemansrätt is an age-old custom. Arguments here may be limited to noting that 'in all times we have been able to do this and that' or refer to the custom as 'being from medieval times' or 'urgammal' (old as our origin). In one Internet site answering frequently asked questions about the Nordic countries, the Allemansrätt is seen as a pan-Nordic custom. It is argued that since Sweden, Norway and Finland had no era of feudalism, personal freedom is important. It is an expression of this that all residents are afforded free access to the forests, lakes and uncultivated land. ${ }^{1}$ Other popular arguments are that in medieval times it was necessary to be able to move where there were no roads, or to camp overnight when on a journey: or that the resources provided by the forest provided an ultimate security for poor people.

Although I am personally of the opinion that the Allemansrät could be argued for in ethical terms, public discourse on the topic usually grounds the argumentation for the Allemansrätt only on its antiquity. When I have tried to question the latter with my friends, I have met very hostile reactions - to do so is more or less heresy.

The uniqueness of the custom, and its centrality to Swedish culture may also be stressed in official information. On one Internet site spreading information on important aspects of Swedish society, three sets of legal rights and obligations are singled out as particularly relevant for understanding Sweden. The Allemansrätt comes first, followed by the Right of Public Access to Official Documents and finally, General Military Service. Threatened by the anti-EUdiscourse about what EU will do to Sweden's Allemansrätt, the Social Democratic Party on its EU information site $^{2}$ on Internet states emphatically: 'EU lacks the authority to maintain any opinion on the Swedish Allemansrätt . It is an entirely Swedish so-called customary right and so falls totally outside the decision making of EU'. 
The idea of the Allemansrätt as a uniquely and primarily Swedish achievement of central value is not limited to official sources. A person who wants to use the Allemansrätt as a metaphor for proper rules in the virtual forest of Internet, refers to it as 'en av de främsta svenska kulturyttringarna' (one of the foremost expressions of Swedish Culture). And a 'proud and peace-loving Swede', writing a letter to the editor of Aftonbladet, ${ }^{3}$ makes an emotional attack against the Swedish spy Stig Bergling:

We Swedes are a patient kind, but now we all have to react. The government's idea of giving Bergling a sentence with a time-limit in practice means that he becomes a free man in some year or two. This must not happen! Stig Bergling is guilty of the most disgusting crime a Swede can commit -- spying against the native country. He has given out information about our military defence. By that he has sold out you, me, our parents, children, children to be, our nature, or way of life, the Allemansrätt, our Swedish freedom, our lives - all for the most mean of all motives, money. If somebody in our society has disqualified himself from being part of our fellowship it is he...

Although the Allemansrätt is often presented as a particularly Swedish achievement, it is nowhere formulated as a right which applies only to Swedes, neither as citizens or residents of the country. Nowadays, with increasing debate on the consequences of integration into the European union and a growth of xenophobia, immigrants, refugees and tourists are more frequently becoming accused of misuse of the custom. They are seen as either not respecting, not understanding or even wilfully taking unjust advantage from the law. Refugees have been accused of 'walking from garden to garden to steal fruit and then appealing to Allemansrätten. ${ }^{4}$ More typically however, the menace is seen as coming from German tourists and investors, who in this context embody popular ideas of Threats To Our Nation. In public discourse, there is still (luckily) in Sweden a hesitation about openly using anti-foreign arguments. Germans would however seem to be among the 'fair game' ethnic categories against whom resentment can be raised without causing much reaction. Expressing surprise, a Dagens Nyheter headline nevertheless states 'The Villain of Nature most often a Swede. Foreign tourists are responsible for a lesser part of crimes against the Allemansrätt' ${ }^{\prime}$.

In educational texts produced by authorities and NGOs on the Allemansrätt it is frequently stated that the right is a right to freedom, but there are also admonitions and exhortations. The right may be a freedom, but subject to responsibility. 'You who enjoy this right have the responsibility and duty to show consideration to (respektera) animals and nature. ${ }^{6}$ The Action Programme of the Tourist Delegation 1995 states that 'The Allemansrätt with its right for individual people to get access to Nature but also a duty to safeguard Nature, is an important resource for Swedish Tourism'. Another Internet site states that 'It is your responsibility to have knowledge about the rules concerning the Right of Public Access!' This duty is specified as a duty to have knowledge about 
particular prohibitions on bathing, boating, water-skiing etc.

What Witoszek (1998: 64) writing on Norway, calls 'the ecological fallacy or the tendency to ascribe features of the landscape to the inhabitants themselves...' is not a very prominent trait in Swedish national naturalism, but the norms of responsible action in relation to nature to some extent reflect Swedish ideals for appropriate interpersonal behaviour, accepting and respecting the right of integrity. The main duty is sometimes expressed as to 'Disturb not, destroy not'. One is told to show 'afterthought' (eftertanke) for example in making up fire. The main object of your concern is Nature itself. Nature has to be approached with reflexive caution so that you do not impose yourself. Although such a norm is not explicitly stated in the texts except in relation to the landowner, this is also how people should be treated. The landowner is seen as in need of domestic privacy, so one should avoid trespassing close to a residential house. When it comes to respecting the landowner, the information usually seems to have been produced for the benefit of the individual visitor to the countryside. Valuable plants, equipment or investments of labour should not be damaged for the landlord, but economic damage in a wider or more abstract sense is not seen as relevant and is usually not referred to.

The assumed threats to the system are often seen as stemming from commercial greed. Indeed, the right to pick mushrooms and berries for sale or preserving has at times been very important to sectors of the rural population and been an argument for rather than against the Allemansrätt. The freedom to move also has a certain economic value apart from the recreational one, as it is a precondition for gathering saleable produce. However it is the secondary marketing of these possibilities on a large scale that creates most protests, whether it is a matter of large groups of German tourists let loose in the forest or in the rapids, or temporary berry pickers coming en masse from Russia or Poland. Wild flowers rarely figure in the discussion of the economic aspects of the system, or the threats against it, but they are still important to the concept of Allemansrätt . It is hard to see why the right to pick something of such limited economic value has to be granted by the constitution, if it were not for the symbolic value. Being allowed to pick berries, mushrooms and wild flower stands as a metaphor for 'having access to Nature'. Elwert (1987) refers to the type of argument heard in the Allemansrätt defence that 'anything should not be for sale' as 'anti-venality'. He notes that many present-day political movements strive to promote a limitation of the principles of market exchange (as against corruption, prostitution etc.) by moral systems regulating trust, positing a 'we-group' within which generalised reciprocity should rule. Anti-venality moves often signify attempts to constitute moral boundaries.

Flowers, berries and mushrooms make up only a small part of what is attractive in forest or meadow. As mentioned, many types of natural produce are 
excluded from the rule. Most notably, hunting rights are rarely mentioned in the same context as the Allemansrätt, not even as a contrast. Wildlife, in contrast to flowers, until a few years ago, played only a limited part in the trivial symbolism of Swedish nationhood. Then, IKEA, the large furniture company, used the elk in marketing. Roughly at the same time, Swedish newspapers reported that the Department of Roads had severe problems with German tourists stealing triangular road signs warning for elk, a serious traffic hazard at certain times of year. In 1996 the Board started to make ugly holes in their own signs, not destroying their utility as warnings, but with the intent to destroy their aesthetic value. However, already two or three years ago the Swedish tourist souvenir business found it a very profitable idea to hook on to the elk demand. The traditional wooden Dala Horse, with connotations of peasant art and rural simplicity, was ousted from its hegemonic position in tourist shops. ${ }^{7}$ The elk has thus turned into an external sign by which Sweden markets itself, but internally it does not yet really signal 'Swedishness'. That is not to say that it does not represent a central cultural theme, just that this theme is not related to Swedishness as such. It pertains rather to the sense of belonging to a local community.

Ekman has in some detail described the elk hunt of Alfta, a community in the region of Hälsingland, in Northern Sweden. What she writes is equally true of many other communities in Swedish forest regions. There, the elk hunt is collectively organised and the meat meticulously shared out in economically significant proportions. 'The elk hunt is a major factor in the local community, and is important in the maintenance of reciprocal kinship networks. It is also an annual event that highlights the sense of belonging and the ideas of equality in the community...The elk hunt also expresses territoriality, as the municipality is divided into a lot of hunting teams which compete with each other in the number of animals shot, as well as demonstrating unity around local values and the maintenance of boundaries against outsiders' (op.cit. p.64). This relation between people and nature actualised by the elk hunt is not brought into focus in public documents on the Allemansrätt. It is as if the issue of being allowed free access to wander and to pick berries and flowers and the issue of rights to hunt belong to completely different worlds of discourse. Neither is the particular place of the elk hunt in Swedish rural communities part of how Sweden presents itself to foreigners, or described as an unique feature of Swedish culture. The cuddly velvet elk marketed to the German tourist is conceptually very far from the game hunted by a community suspicious about people from the next river valley and even more reluctant to include people from the capital or from abroad. A landowner who is a summer guest, and not an integrated member of the local community has a legal right to a share in game hunted on or over his grounds. Yet he cannot count upon it from a moral point of view: the likelihood is that it will create bad feelings and irritation if he insists. 


\section{A CHALLENGE FROM THE RIGHT}

As I was thinking about this paper, I found out that a new book was about to be published on the Allemansrätt. The book, by Gunnar Wiktorsson, is called (in translation) The Constitutional Myth - on the Launching of Every Man's Right in Sweden. It claims scientific status, being published by The City University, a generally conservative institution which claims to be a private university, (although it has no official status as such). The book overtly expresses its political goal, that is to promote the protection of individual property rights against infringement. It sets out with a thorough, and it has to be admitted, rather useful overview of the legal development of the codified Allemansrät . Over the centuries, neither have the landowner's rights to exclude intruders nor the public's claim to get access been sufficiently self-evident to stop endless legal conflicts over the extent of the rights involved. Wiktorsson's version of history goes like this: According to the old provincial laws (landskapslagar) of medieval Sweden the village communities used to have some commons, in which outsiders to the community were not allowed. These were of great economic significance to the villagers because of various produce such as timber, game, bark, tar and so on. Mushrooms and berries were however not eaten, or of very limited importance due to their limited nutrient value and to storage problems (forgetting lingon-berries, which store well). Outside these community commons there were lands that were unused or unclaimed, until Gustavus I Vasa claimed all such space as regal property. When did the legal rights of mobility and of gathering became problems to discuss for the law-givers? First with the expanson of state or company-owned forests, secondly with the creation of a population of landless poor or rural tenants in the early 19 th century. The landless competed with the landowners over some of the forest resources, especially when better communications and more easy access to sugar paved the way for an export of berries to Germany. The growth of an industrial population created new conflicts, first over the forest resources, then by the expansion of an urban need for recreation, and a political concern that recreational resources should not be monopolised by the wealthy. A general notion of a customary Allemansrätt, accessory to citizenship but based in ancient history was then launched by certain lawyers in the first decades on this century. In Wiktorsson's view this was done on rather loose grounds. The real breakthrough for the concept, even the minting of the word with its archaic ring, came with the Governmental Investigation on Recreation (Fritidsutredningen) in the 1940s.

As a political statement the book is a rather curious piece of work. As is obvious from the title of the book the author's argument is based on the general view that the Allemansrätt is a constructed myth. He assumes that by deconstructing the truth value of the various central themes in the discourse surrounding the Allemansrätt, one could also dismantle the myth. Wiktorsson notes the same dominant traits in the discourse on the Allemansrätt as I have done 
myself. Thus, it is mainly by attacking the idea of an ancient origin that he in his book tries to undermine ' the myth'. What an anthropologist would regard as an analysis of the 'invention of tradition' is here not only used to reflect on how culture is constantly shaped and reshaped, but as a strong political argument. As a counter-argument Wiktorsson's argument therefore reflects the same basic conceptualisation as the argument under attack: morality, righteousness and truth are linked to what is original or of great historical antecedent. However, as most anthropologists are aware nowadays, customary law is always renegotiated, even when it claims to be based on tradition. Furthermore, the public sense of justice in a stratified society is always likely to be position-specific. What was regarded as morally right by the medieval poor probably left too few traces for us ever to know whether they thought in terms of the Allemansrätt or not.

Making a politically dismantling constructivist analysis differs from making a scientific one by the weight afforded to the importance of truth claims. There is in the former a tendency to 'deconstruct' only the inexpedient aspects of the enemy's arguments and not the counter-arguments used by oneself. Wiktorsson shares some of the premises of the pro-Allemansrätt discourse, reflecting the bases of everyday thinking about identities. Among them are the following notions: (a) the origin of a custom imprints on it its essential meaning, (b) what is ancient is more authentic, and (c) uniqueness defines what is important to identity. Having shown the Allemansrätt is not an ancient customary rule, one could perhaps have expected him to put forward some alternative system of rights as more Swedish than the Allemansrätt. Wiktorsson wants to demonstrate first that it is not unique to Sweden, then that it is not democratic or even Swedish in origin, and finally, that it represents urban contempt for the farmer. His own passionate cause is in defence of individual and inalienable property rights. They are the basic pillar on which rests the individuals' protection against an intrusive and oppressive state. Such rights are not presented as authentic to Sweden, but as an elaboration of Roman rights which have improved what was before a patriarchal, stratified and constraining society.

Nevertheless, Wiktorsson develops the thread of something un-Swedish and undemocratic by suggesting that the legal expertise and some of the lobbying groups - such as Friluftsfrämjandet ('The Association for Outdoor Promotion') who were involved in the Investigation on Recreation of the forties were inspired by Nazi ideology, especially when it came to the idea of inner and outer strengthening through a healthy life. He makes a rhetorical connection between this idea and the totalitarian threat implied in his reading of the Allemansrätt as a case where Society, representing the oppressive majority, infringes on individual freedom. He links these notions with references to German rather than Roman Right involved in the early formulations of the Allemansrätt. Certainly there were both direct ideological imports from Germany and some common elaboration in both countries of ideas circulating at that time, touchy as these issues may be. However Wiktorsson's argument which ultimately equalises 


\section{GUDRUN DAHL}

Social Democracy with National Socialism is not very solid and contains several insinuating assumptions that cannot be taken seriously. It has rather to be seen as an attempt to challenge the idea that the notion of Allemansrätt is ultimately Swedish by appealing not only to anti-nazism but also to the same Germanophobia that is part of the anti-tourist campaigns.

Wiktorsson notes that in the discussions regarding the change of constitution, all political parties supported the codification of the Allemansrätt as an inalienable right, and reflects that it seems to lend itself to interpretation from different angles (p. 223) He assumes (in both cases wrongly) that the Social Democrats 'for sure' read the Allemansrätt as 'a symbol for Socialism and for Swedish ground having long been socialised' and that the Moderates 'surely' see it as 'a symbol of freedom, of Sweden having since time immemorial furthered the right of the individual to ramble freely...'

\section{NATIONAL - YET HUMAN?}

Having written the law into our constitution, it is from a legal point of view in our capacity as citizens that we Swedes have this right. Bonyhady notes in the introduction to his 'Law of the Countryside' about Britons that 'When considering their rights as individuals, people ordinarily think of their 'fundamental freedoms' or civil liberties - freedom of expression, freedom of religion and so on. They rarely consider questions of land law or issues involving the environment'. This does not apply to Sweden. The freedom to move is thought of as fundamental and is thoroughly embedded in the word's most concrete sense. Contrary to Wiktorsson' s argument, in conceptualising the moral basis of the Allemansrätt, few Swedes whether Social Democrat or not, think of it as a right held by Society, or as a right held by the State in which we as citizens have a share. Rather, it is thought of as a natural human right, which ought to be valid everywhere. Swedes become indignant when it does not apply, for example, when we are in England forced to 'stick to the public footpath'. If it is Swedish it is because it gives us explicit access to particular and strongly emotionally loaded Swedish symbols and because we (falsely, for sure) believe that it is only we that are enlightened enough to recognise this fundamental human right and to have a particular love for Nature as such.

Used as a space for recreation, the Swedish forest is un-gendered, un-classmarked. It has no distinctions. It cannot be divided by property or by symbols exclusively appropriated by any segment of society (cf. Frykman and Löfgren $n 5 p$ 58.) Thus it speaks to us as equals. It contains few signs of property readily understood by the urbanite. Fences, usually walls of piled stone, are often climbed. They are often broken down by visitors who do not see their functional significance. Even the fact that the Allemansrät $t$ was for long not formalised, and 
still is not wholly spelt out, can be read as a message in itself. The rule, considered as a 'right', is seen as a 'natural' expression of the assumed essence of being Swedish or even of being human. Therefore it should need no backing. It pertains to what Swedes are before they have become tied down by society's strictures and divisions, something beyond legalisation and bureaucracy.

I would argue then, that the Allemansrätt certainly is a historically situated construction. Yet it stands, for the middle-class Swede, not only as an expression of the values of equality and freedom but also a key symbol for these values. At another level, it refers to shared access to another key cluster of symbols, the Swedish Summer, and all its implications of national tradition. At the surface it does so in a rather neutral way, which does not immediately invite antichauvinist criticism. Nevertheless, this reassuring neutrality may be rather spurious. As a form of 'banal nationalism', not based on language, nor race nor citizenship, it may actually rest too much upon a fund of common personal experience too be sufficiently accommodating and non-excluding in the long run to 'new Swedes' with other childhood experiences than the normative blueberry picking summer vacation.

\section{NOTES}

${ }^{1}$ http://www.lysator.liu.se/nordic/scn/faq21.html

${ }^{2}$ http://www.sap.se/europa/34.htm\#2

${ }^{3}$ July 181996

${ }^{4}$ (Lövström, Håkan 1989 ' Poliser' på gatan löser rasbråk direkt' Svenska Dagbladet qu by Klein Not 2, p 57)

${ }^{5}$ ( DN 16 dec 94)

${ }^{6}$ (www.Allemansrätten):

${ }^{7}$ However, only to be very forcefully pushed back into the market in $1998 \ldots$

\section{REFERENCES}

Billig, Michael 1995. Banal Nationalism. London: Sage.

Bonyhady, Tim 1987. The Law of the Countryside: The Rights of the Public. Oxford: Oxford Professional Books.

Bourdieu, Pierre and Jean-Claude Passeron. 1977. Reproduction in Education, Society and Culture. London: Sage. (Translation of Bourdieu and Passeron, Fr. ed.: 1970. La reproduction: éléments pour une théorie du système d'enseignement. Paris: Éditions de Minuit.)

Boesen, Jannik and Philip Raikes 1976. 'Politsk økonomi og planlægning i Tanzania'. Den Ny Verden 10(4). København: Udgivet af Centret for Udviklingsforskning.

Ekman, Ann Kristin 1991. Community, Carnival and Campaign: Expressions of Belonging in a Swedish Region. Stockholm Studies in Social Anthropology, vol 25 


\section{GUDRUN DAHL}

Ellen, Roy 1996. 'The Cognitive Geometry of Nature: A Contextual Approach', in Philippe Descola and Gisli Pàlsson (eds) Nature and Society: Anthropological Perspectives, pp. 103-124)

Elwert, Georg 1987. 'Ausdehnung der Käuflichkeit und Einbettung der Wirtschaft'. Zeitschrift fur Soziologie und Sozialpsychologie: 300-321.

Firth, Raymond 1973. Symbols, Public and Private. London: George Allen and Unwin. Hylland-Erikssen, Thomas 1995. 'Norrmännen gör som sköldpaddan. Under Strecket'. Svenska Dagbladet.

Klein, Barbro 1993. 'Fences, Fertilizers and Foreigners: Moral Dilemmas in the Swedish Cultural Landscape'. Journal of Folklore Research 30.

Löfgren, Orvar 1987. 'The Nature Lovers', in Jonas Frykman and Orvar Löfgren (eds) Culture builders a historical anthropology of middle-class life, transl. by Alan Crozier, pp. 42-87. New Brunswick: Rutgers University Press.

Löfgren, Orvar 1989. 'Landscapes and Mindscapes'. Folk 31: 183-208.

Sörlin, Sverker 1988. Framtidslandet: Debatten om Norrland och naturresursema under det industriella genombrottet. Kungl. Skytteanska Samfundets handlingar 33. Stockholm: Carlsson bokförlag.

Wiktorsson, Gunnar 1996. Den grundlagsskyddade myten: Omallemansrättens lansering i Sverige. Stockholm.

Witoszek, Nina 1998. Naturmytologier: Fra Edda til Ökofilosofi. Oslo: Pax Forlag. Zetterholm, Finn 1969. Barnvisan i Sverige. Barnvisans blomstring kring sekelskiftet. Bakgrund, genrer och motiv. Stockholm: Proprius. 